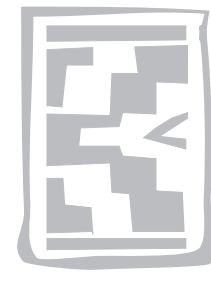

\title{
Responses of serum electrolytes of goats to twelve hours of road transportation during the hot-dry season in Nigeria, and the effect of pretreatment with ascorbic acid
}

\author{
J.O. AYO ${ }^{1}$, N.S. MINKA ${ }^{2 *}$, A.K.B. SACKEY ${ }^{3}$ and A.B. ADELAIYE ${ }^{4}$
}

\begin{abstract}
AYO, J.O., MINKA, N.S., SACKEY, A.K.B. \& ADELAIYE, A.B. 2009. Responses of serum electrolytes of goats to twelve hours of road transportation during the hot-dry season in Nigeria, and the effect of pretreatment with ascorbic acid. Onderstepoort Journal of Veterinary Research, 76:409-418

Twenty goats which served as the experimental group were administered ascorbic acid (AA) per os at a dosage rate of $100 \mathrm{mg} / \mathrm{kg}$ body mass, while 20 others served as controls and were given $10 \mathrm{ml}$ each of sterile water. Forty minutes after the administration and loading, the goats were transported for $12 \mathrm{~h}$. Handling and loading of the experimental and control groups of goats decreased $(P<0.05)$ the potassium and sodium serum concentrations. The concentration of serum chloride, sodium and calcium increased significantly $(P<0.05)$ immediately post-transportation, while potassium and magnesium decreased $(P<0.05)$ in the control goats. In AA-treated goats sodium and magnesium concentrations decreased abruptly $(P<0.05)$, while calcium increased significantly $(P<0.05)$ after transportation. Handling, loading and transportation adversely affected the electrolyte balance of the goats which suggested respiratory alkalosis, dehydration and muscular damage in the transported goats, and the administration of AA alleviated the adverse effects of road transportation stress on serum electrolytes.
\end{abstract}

Keywords: Ascorbic acid, electrolyte, goat, road transportation, stress

\section{INTRODUCTION}

Long distance road transportation of livestock causes complex pathophysiological changes, induced by handling, loading, transportation, introduction to a new environment, vehicle motion, noise and vibra-

* Author to whom correspondence is to be directed: E-mail: mnsalka@yahoo.com

1 Department of Physiology and Pharmacology, Faculty of Veterinary Medicine, Ahmadu Bello University, Zaria, Nigeria

2 College of Agriculture and Animal Science, P.M.B. 2134. Division of Agricultural Colleges, Ahmadu Bello University, Mando - Kaduna, Nigeria

3 Department of Surgery and Medicine, Faculty of Veterinary Medicine, Ahmadu Bello University, Zaria, Nigeria

4 Department of Physiology, Faculty of Medicine, Ahmadu Bello University, Zaria, Nigeria

Accepted for publication 16 April 2009-Editor tion, and the concomitant effect of adverse climatic conditions (Knowles, Warriss, Brown \& Edwards 1999; Rajion, Soat, Zulkifli \& Goh 2001; Kannan, Terril, Kouokou, Gelaye \& Amoah 2002; Minka \& Ayo 2007a, b, 2008).

Transportation of goats is fast expanding worldwide due to the increased demand in goat meat and skin, the latter being highly prized and is used in leather industries (Kannan et al. 2002). The majority of studies conducted on the transportation of goats are done in temperate regions of the world (Rajion et al. 2001) and measures aimed at alleviating road transportation stress in goats are still limited (Galipalli, Gadiyaram, Kouakou, Terril \& Kannan 2004; Minka \& Ayo 2007b). Important limiting factors affecting goats transported by road in tropical countries are high ambient temperature (AT) and relative humidity $(\mathrm{RH})$ occurring during the hot-dry season 
of the year (Rajion et al. 2001; Minka \& Ayo 2007b). High AT and $\mathrm{RH}$ have been responsible for increased mortality, morbidity, loss in live mass, dehydration and poor meat quality, which often result in considerable economic losses (Rajion et al. 2001, Minka \& Ayo $2007 a, b)$. In addition, the majority of goats in tropical regions are reared under extensive management systems and are difficult to handle. This compound the stress encountered during rounding-up, handling and loading, which have been established as the biggest stress factor during road transportation of animals (Plyanschenko \& Sidorov 1987; Knowles et al. 1999; Rajion et al. 2001).

It has been shown that long distance road transport affects the electrolytes of cattle and roe deer; the major ions being affected include chloride, potassium, calcium magnesium and sodium (Atkinson 1992; Schaefer, Jones, Jones \& Stanley 1990, 1997; Montane, Marco, Lopez-Olvera, Manteca \& Lavin 2002; Parker, Hamlin, Coleman \& Fitzpatrick 2003b). Management strategies towards stabilizing electrolyte balance in transported animals have been proposed by supplementing one or more dietary elements before, during or after transportation (Philips 1997; Schaefer et al. 1990; Chang \& Mowat 1992; Ross, Spears \& Garlich 1994; Parker et al. 2003b; Ali, AlQarawi \& Mousa 2006). In spite of some attenuating effects of these supplements, such treatments are also known to have limitations. If applied improperly they can be counter-productive, with greater consequential effects on both animals and humans (Kaneko 1980; Sranmek \& Pozdeseu 1987), and some studies have showed that supplementation did not have any effect (Parker et al. 2003b; Galipalli et al. 2004). Thus, the need to search for more reliable, cheaper, non-toxic and easily administered agents has become paramount.

There is a paucity of information on the effect of long distance road transportation on the electrolytes of Red Sokoto goats (RSG) during the annual hotdry period of Nigeria. Recently, the administration of ascorbic acid (AA) prior to transportation of goats and poultry has been shown to ameliorate the adverse effects of road transportation stress on rectal temperature, excitability score, live mass, behaviour and haematology (Ayo, Minka \& Mamman 2006; Minka \& Ayo 2007b; Minka \& Ayo 2008). Ascorbic acid is a potent antioxidant vitamin known to protect cells from oxidative stress and lipid peroxidation (Tauler, Aguilo, Gimeno, Fuentespis, Tur \& Pons 2003). It has been shown to enhance animals' adaptational capability to environmental stress (Hassanzadeh, Buys, Dewl, Rahimi \& Gecuypere 1997; Minka \& Ayo 2008).
The present study was aimed at examining in detail the sequential changes in the concentration of serum minerals of goats administered AA and transported by road for $12 \mathrm{~h}$ during the hot-dry season of Nigeria.

\section{MATERIALS AND METHODS}

\section{The Red Sokoto or Maradi goat}

The Red Sokoto goat is characterized by a uniformly dark-red coat colour, short and horizontal ears, and horns in both sexes. The goats are mostly reared under the traditional extensive management system. They serve as a good source of meat, the high quality skin is used in leather industries and they provide an income to the small scale farmer. Males are heavier (average of $27 \mathrm{~kg}$ ) than the females (average of $25 \mathrm{~kg}$ ). The breed is extremely resistant to the harsh environmental conditions and nutritional stress prevailing in the northern Guinea Savannah zone of Nigeria, which has contributed to its great population density in West and North African regions.

\section{Experimental site and meteorological data from the study area}

The experiment was conducted at Livestock Farm, College of Agriculture and Animal Science, Ahmadu Bello University, Kaduna ( $\left.11^{\circ} 10^{\prime} \mathrm{N}, 07^{\circ} 38^{\prime} \mathrm{E}\right)$, which is located in the northern Guinea Savannah zone of Nigeria. Transportation of the goats was conducted during the hot-dry season (April) from Kaduna to Makera $\left(12^{\circ} 31^{\prime} \mathrm{N}, 06^{\circ} 11^{\prime} \mathrm{E}\right)$ and from Makera back to Kaduna, the total distance being $600 \mathrm{~km}$.

The meteorological data of the dry-bulb temperature, relative humidity, sunshine duration and wind direction were recorded at the experimental site at 06:00,13:00 and 18:00 daily for 7 consecutive days before and after transportation. Values of these parameters were also recorded at each 12-h transportation period which commenced at 7:00 and ended at 19:00, and after unloading the goats from the vehicle at the first, second and third hour post-transportation. The dry-bulb temperature and relative humidity were measured using a wet- and dry-bulb thermometer (Cocet, Shenzhen-Guangdong, China).

\section{Animals and management}

Forty Red Sokoto goats, including males and nonpregnant females, aged 2.5-3 years old and weighing between $23-25 \mathrm{~kg}$, served as subjects of the study. They were obtained from within the study area 3 weeks before the study commenced and were 
housed in a standard goat pen measuring $10 \mathrm{~m}$ long by $5 \mathrm{~m}$ wide and $2.5 \mathrm{~m}$ high. The top half of the wall of the pen was open and was provided with a wire mesh for adequate ventilation. The roof of the pen was made of aluminium with a wooden ceiling, while the floor was concrete. The goats were not restrained inside the pen and were stocked at a rate of $1 \mathrm{~m}^{2}$ per goat (Kannan et al. 2002). They were herded out and grazed on an improved natural pasture from 09:00 to 18:00 every day and were given access to drinking water ad libitum. The pasture on which the goats grazed was characterized by browse shrubs, shoots of guinea corn, maize and guinea corn residues, and groundnut hay.

Three weeks before the transportation, the goats were prophylactically treated against ectoparasites with cypermethrin (Cypermethrin Pour On; Ourofino, Brazil) at a dose of $1 \mathrm{ml} / \mathrm{kg}$ body mass, haemoprotozoa with diminazine aceturate (Nozomil; Kepro B.V., Holland) at a dose of $3.5 \mathrm{mg} / \mathrm{kg}$ of body mass by deep intramuscular injection, and endoparasites with albendazole (Unaben; Neineth, Lagos, Nigeria) given orally at a dose of $0.8 \mathrm{mg} / \mathrm{kg}$.

\section{Experimental design}

Two days before the commencement of the experiment, an area of about $3 \times 4 \mathrm{~cm}$ at the site of the location of the jugular vein on the mid-third of the left side of the neck was shaved to facilitate venipuncture. On transportation day before the journey, the goats were randomly allocated into experimental and control groups, each consisting of 20 goats. During handling, at 06:00 before loading, ten goats from each group were bled to obtain pre-loading baseline values. At the same time all the goats in the experimental group were orally given AA (Sigma Chemical, St. Louis, MO, USA) at a dose of $100 \mathrm{mg} / \mathrm{kg}$ body mass (Chervyakov, Yevdokimov \& Vishker 1977; Minka \& Ayo 2007b), dissolved in $10 \mathrm{ml}$ of sterile water, while each of the control goats was administered orally with $10 \mathrm{ml}$ of sterile water. Goats that were bled were coloured-marked for easy identification. They were then all loaded onto the vehicle. The handling and loading of the goats took about 40 min. After loading and immediately before the commencement of the journey, blood samples were quickly obtained from the other ten goats in each group that had not previously been bled to determined the effects of handling and loading. They were then transported for $12 \mathrm{~h}$ on a tarred road from Kaduna to Makera and from Makera back to Kaduna at a speed of $40-50 \mathrm{~km} / \mathrm{h}$. On completion of the journey, the goats were returned to the same pen, offered feed and water and managed as they had been before their transportation. Immediately after transportation, $12 \mathrm{~h}$ after, and on the $3^{\text {rd }}$ and $7^{\text {th }}$ day post-transportation, all the goats in both the experimental and control groups were bled. Food was withdrawn from the goats $6 \mathrm{~h}$ before transportation and throughout the 12-h journey, while water was withheld only during the journey period (Greenwood, May \& Finn 1993; Richardson 2002).

\section{Handling and loading}

The handling, loading and transportation of the goats were carried out humanely in accordance with the guidelines governing animal transport welfare by road (Anon. 1991; Farm Animal Welfare Council [FAWC] 2003; Richardson 2002; Minka \& Ayo 2007b). Briefly, the floor of the loading deck of the vehicle was covered with wood shavings and the loading of the goats was performed individually by two persons. Under relatively calm conditions, one person randomly caught one goat at a time and lifted it up by supporting it with his hands under the abdomen and handed it to the other person who was on the loading deck who, in turn restrained each animal by tying one end of a sisal rope, $70 \mathrm{~cm}$ long around its neck and the other end to a metal rod attached to the vehicle's sides. The rope was long enough for each animal to freely turn and lie down. The goats were stocked at a rate of $0.3 \mathrm{~m}^{2}$ per animal and were stocked so that they formed two rows against the direction of the movement of the vehicle. The loading was conducted between 06:00 to 07:00.

\section{Vehicle design and journey time}

A standard Bedford pick-up van popularly used in the Guinea Savannah region of Nigeria for the transportation of animals and goods was used for the journey. The floor of the loading deck consisted of thick wooden planks, and was $7.5 \times 1.5 \mathrm{~m}$ in extent and $1.5 \mathrm{~m}$ from the ground. Its side walls were $0.6 \mathrm{~m}$ high and constructed of corrugated aluminium sheets, to which the holding rods had been fastened. The floor of the deck was covered with wood shavings placed on rubber mats to provide secure footing for the animals but there was no roof. The journey commenced at 7:00 and ended at 19:00. During the journey the vehicle travelled for $12 \mathrm{~h}$ on a typical Nigerian asphalt single lane road, from Kaduna to Makera town and then back to Kaduna, a total distance of $600 \mathrm{~km}$. The vehicle travelled at an average speed of $50 \mathrm{~km} / \mathrm{h}$ and was driven by two licensed drivers whose driving styles were similar to each other. Each driver drove the vehicle in turn for $6 \mathrm{~h}$. During the journey, 
the vehicle had four stop-overs at veterinary and police control posts, each lasting less than $3 \mathrm{~min}$. The goats were rested for $1 \mathrm{~h}$ after each 8-h transportation period, in adherence to international transport welfare order (Anon. 1991). During the resting periods, the vehicle was parked in shade to avoid the direct effect of sunlight and rapid build-up of heat inside the vehicle (Richardson 2002).

\section{Blood sampling and analyses of serum electrolytes}

At each blood sampling $5 \mathrm{ml}$ of blood were collected by venipuncture of the jugular vein of each goat using disposable syringes and a $0.8 \times 25 \mathrm{~mm}$ needle. Each blood sample was dispensed into a sterile test tube without any anticoagulant, and the collected samples were taken as quickly as possible to the Research Laboratory, College of Agriculture and Animal Science, Ahmadu Bello University, Kaduna where they were kept at room temperature until the blood had clotted. Thereafter it was centrifuged at 3000 rpm for 10 min and the serum content was kept at $-18^{\circ} \mathrm{C}$ until analysed which was done 3 days after collection at the Clinical Laboratory, Ahmadu Bello University Zaria, Nigeria. Serum concentrations of $\mathrm{Na}, \mathrm{K}, \mathrm{P}, \mathrm{Ca}$ and $\mathrm{Mg}$ were analysed using plasma atomic emission spectrophotometer (Varian Australia Pty Ltd., Melbourne, VIC, Australia), and plasma chloride by means of a chloride meter (Jenway PCLM3, Essex, England).

\section{Statistical analysis}

All data obtained were subjected to Student's $t$-test. Data were expressed as mean \pm standard error of the mean (Mean \pm SEM). Values of $P<0.05$ were considered significant.

\section{RESULTS}

\section{Meteorological conditions}

The AT measured at 07:00 and 14:00 during the study period had minimum and maximum values of $20.0^{\circ} \mathrm{C}$ and $39.4{ }^{\circ} \mathrm{C}$, respectively. The AT had a mean value of $36.7 \pm 0.2^{\circ} \mathrm{C}$, the $\mathrm{RH}$ values fluctuated between $65 \%$ and $75 \%$ with a mean value of $65.5 \pm 5.6 \%$. During the transportation, especially in the hot afternoon period of the day, the AT inside the vehicle rose with the duration of the journey from $28.2^{\circ} \mathrm{C}$ to a maximum of $40.1^{\circ} \mathrm{C}$ at $14: 00 \mathrm{~h}(\mathrm{r}=0.895$, $P<0.01)$. Thereafter it decreased to $34.0^{\circ} \mathrm{C}$ during the last hour of the journey. The mean AT recorded during the journey was $37.2 \pm 1.3^{\circ} \mathrm{C}$, while the $\mathrm{RH}$ was $75.4 \pm 1.8 \%$. The sunshine duration on the day of journey was $12.5 \mathrm{~h}$.

\section{Serum concentration of electrolytes}

Fig. 1 depicts the changes in serum chloride concentrations pre- and post-transportation period. Serum chloride concentrations of $89 \pm 2.2 \mathrm{mmol} / \ell$ and 91.0 $\pm 1.2 \mathrm{mmol} / \ell$ obtained in the experimental and control goats, respectively.

Post-loading were not different $(P>0.05)$ between the groups or from the pre-loading concentration of

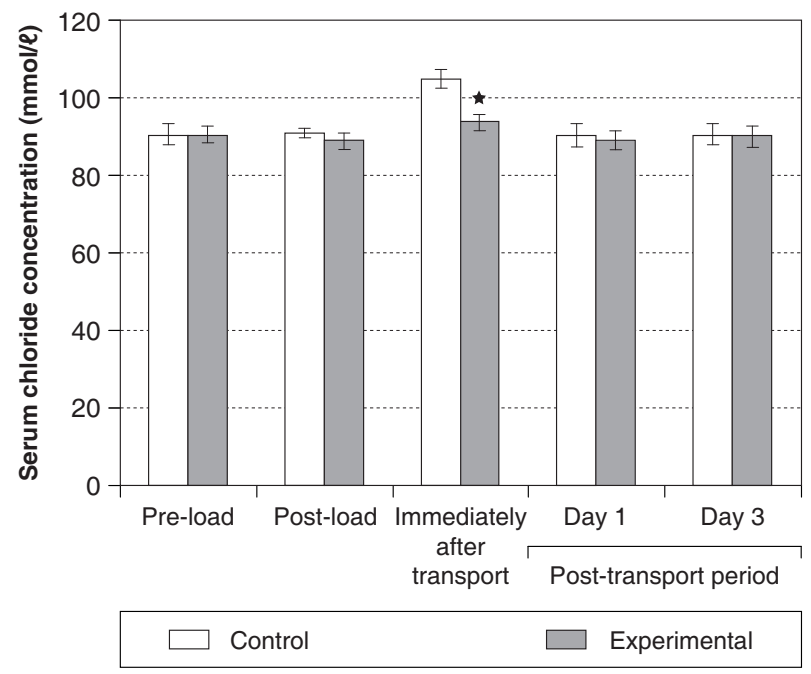

FIG. 1 Effect of loading, transportation and post-transportation stress on serum chloride concentration of the experimental $(n=20)$ and control $(n=20)$ goats

${ }^{*} P<0.05$

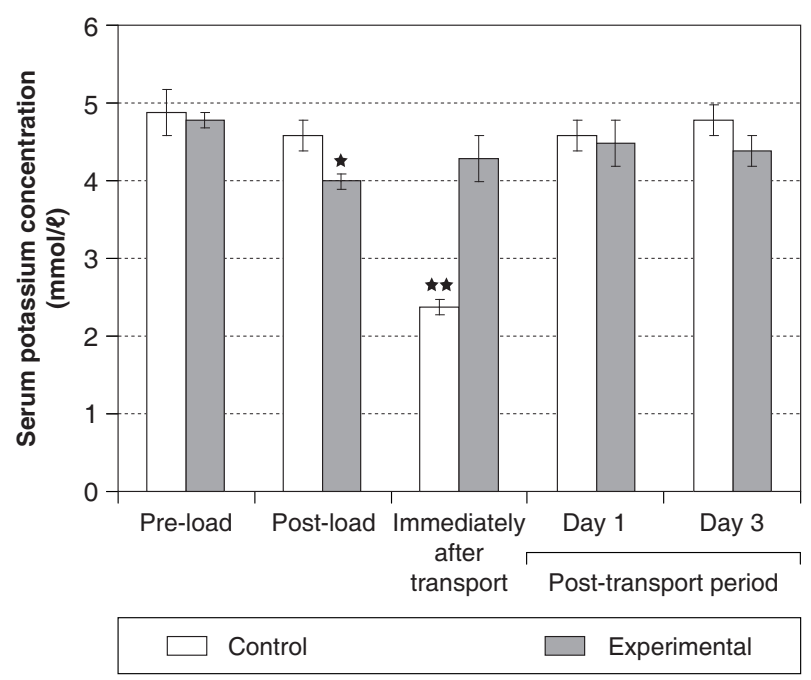

FIG. 2 Effect of loading, transportation and post-transportation stress on serum potassium concentration of the experimental $(n=20)$ and control $(n=20)$ goats

$$
{ }^{*} P<0.05 \quad \text { ** } P<0.01
$$


$90.5 \pm 2.9 \mathrm{mmol} / \ell$. However, immediately after transportation the post-transportation serum chloride concentration of $105.7 \pm 3.0 \mathrm{mmol} / \mathrm{l}$ obtained in the control goats was significantly higher $(P<0.05)$ than the post-loading value and the corresponding value of $93.7 \pm 2.0 \mathrm{mmol} / \mathrm{l}$ obtained in the experimental goats. In the experimental goats, the value of $93.7 \pm 2.0$ $\mathrm{mmol} / \mathrm{\ell}$ obtained post-transportation did not differ $(P$ $>0.05$ ) from the pre-loading value. Serum chloride concentrations returned to baseline values $12 \mathrm{~h}$ after transportation in all the goats.

Fig. 2 shows changes in serum potassium levels of the goats to the effects of $12 \mathrm{~h}$ road transportation and the administration of AA. Serum potassium levels decreased in the experimental goats from the pre-loading value of $4.8 \pm 0.1 \mathrm{mmol} / \ell$ to a post-loading value of $4.0 \pm 0.1 \mathrm{mmol} / \ell$. In the control goats, there was no significant $(P>0.05)$ difference between the potassium concentration from the preloading concentration of $4.9 \pm 0.3 \mathrm{mmol} / \ell$ to a postloading concentration of $4.6 \pm 0.2 \mathrm{mmol} / \mathrm{l}$. However, after transportation, the potassium concentration decreased $(P<0.01)$ to $2.4 \pm 0.1 \mathrm{mmol} / \ell$ in the control goats and the value was lower $(P<0.05)$ than the corresponding value recorded in the experimental goats. Base-line values in all the goats were attained $12 \mathrm{~h}$ after transportation.

The response of serum sodium concentration to the effects of loading, administration of AA and road transportation is shown in Fig. 3. Sodium concentration decreased significantly $(P<0.05)$ from the

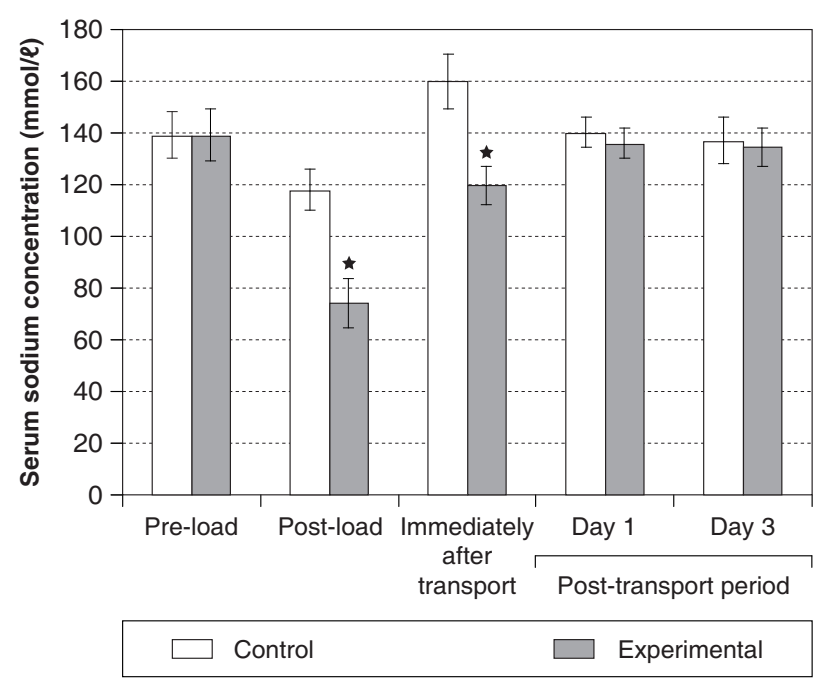

FIG. 3 Effect of loading, transportation and post-transportation stress on serum sodium concentration of the experimental $(n=20)$ and control $(n=20)$ goats

${ }^{*} P<0.05$ pre-loading concentration of $139 \pm 9.2 \mathrm{mmol} / \mathrm{\ell}$ to post-loading value of $118.2 \pm 7.5 \mathrm{mmol} / \ell$ and $73.4 \pm$ $9.4 \mathrm{mmol} / \mathrm{\ell}$ in the control and experimental goats respectively. After transportation, sodium concentrations increased $(P<0.05)$ to the value of $160 \pm 10.2$ $\mathrm{mmol} / \mathrm{l}$ in control goats, compared to the value of $120 \pm 7.5 \mathrm{mmol} / \mathrm{l}$ recorded in the experimental goats' post-transportation period. In both the experimental and the control goats base-line values of sodium were returned $12 \mathrm{~h}$ after transportation.

Fig. 4 depicts the changes in serum calcium concentrations during the pre- and post-transportation periods. Serum calcium concentrations were not affected by loading in either the experimental or the control goats. However, calcium concentrations increased significantly in control goats from a mean pre-loading value of $2.2 \pm 0.1 \mathrm{mmol} / \ell$ to a posttransportation concentration of $4.1 \pm 0.2 \mathrm{mmol} / \ell$, this value being significantly $(P<0.05)$ higher than the corresponding value of $3.2 \pm 0.3 \mathrm{mmol} / \ell$ recorded in the experimental goats post-transportation. Baseline values were obtained $12 \mathrm{~h}$ after transportation in the experimental goats, while in the control goats base-line values were returned after 3 days into the post-transportation period.

Handling, loading, transportation and administration of AA had no effect on the serum phosphate concentrations of either the experimental $(1.9 \pm 0.2 \mathrm{mmol} / \ell$ pre-loading to $2.1 \pm 0.1 \mathrm{mmol} / \mathrm{\ell}$ post-transportation) and the control $(2.0 \pm 0.1 \mathrm{mmol} / \ell$ pre-loading to 2.1 $\pm 0.1 \mathrm{mmol} / \ell$ post-transportation) goats (Fig. 5).

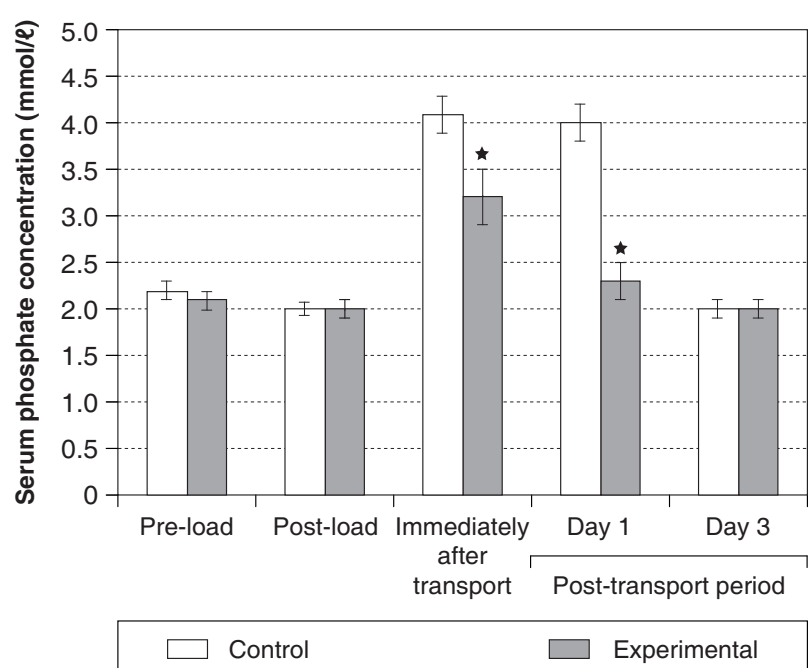

FIG. 4 Effect of loading, transportation and post-transportation stress on serum calcium concentration of the experimental $(n=20)$ and control $(n=20)$ goats

${ }^{*} P<0.05$ 


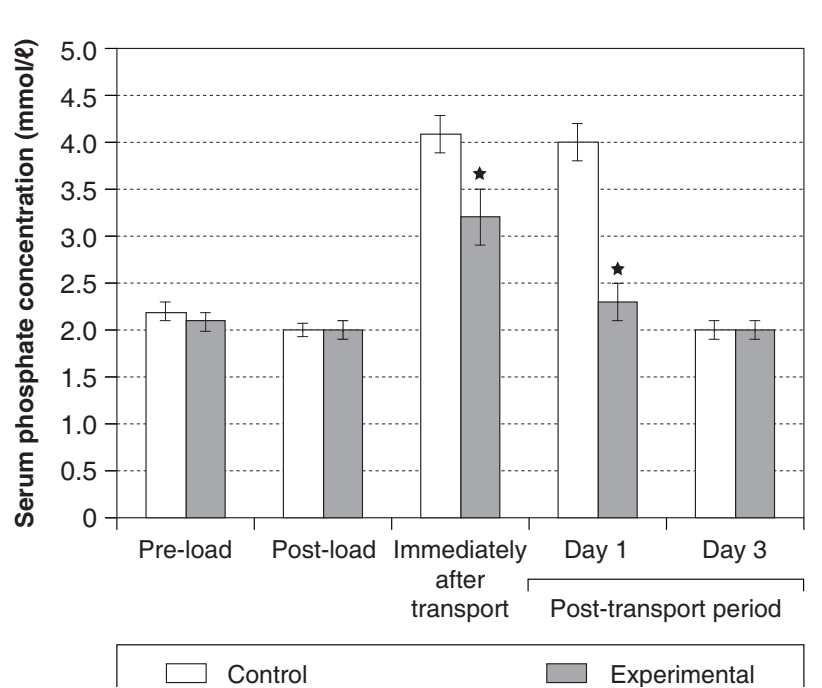

FIG. 5 Effect of loading, transportation and post-transportation stress on serum phosphate concentration of the experimental $(n=20)$ and control $(n=20)$ goats

${ }^{*} P<0.05$

The magnesium concentrations were not affected by loading, in either group of goats. In the experimental group, the mean serum $\mathrm{Mg}$ concentration decreased insignificantly $(P<0.05)$ from the postloading value of $1.0 \pm 0.06 \mathrm{mmol} / \ell$ to a post-transportation value of $0.8 \pm 0.04 \mathrm{mmol} / \ell$, while in the control goats the mean $\mathrm{Mg}$ concentration decreased significantly $(P<0.05)$ to a post-transportation value of $0.52 \pm 0.05 \mathrm{mmol} / \ell$, this being lower $(P<0.05)$ than the corresponding value recorded in the experimental group. In this group the mean base-line value was returned $36 \mathrm{~h}$ post-transportation. In the experimental goats, base-line $\mathrm{Mg}$ values were returned within $12 \mathrm{~h}$ of transportation (Fig. 6).

\section{DISCUSSION}

The meteorological data recorded during the study period was characterized by high $\mathrm{AT}, \mathrm{RH}$ and prolonged solar radiation, typical of the hot-dry period in the Northern Guinea Savannah zone of Nigeria. The minimum, maximum and mean AT values recorded in the study area pre- and post-transportation periods were higher than those in temperate zones which range between $12-24{ }^{\circ} \mathrm{C}$ (Nikitchenko, Plyaschenko \& Zenkov 1988). Similarly, the maximum and mean AT values of $39.7^{\circ} \mathrm{C}$ and $36.7^{\circ} \mathrm{C}$ recorded at the site of the study area were higher than the upper heat tolerance limit value of $35^{\circ} \mathrm{C}$ established for goats in hot regions of the world (Richardson 2002). The results demonstrate that the meteorological values were markedly outside

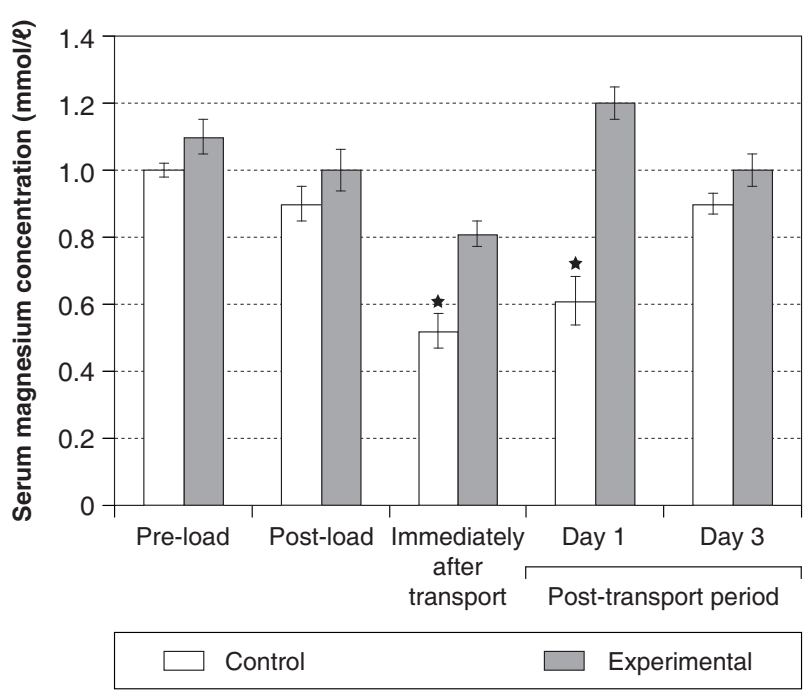

FIG. 6 Effect of loading, transportation and post-transportation stress on serum magnesium concentration of the experimental $(n=20)$ and control $(n=20)$ goats

${ }^{*} P<0.05$

the optimal thermo-neutral zone of $22-35^{\circ} \mathrm{C}$ established for goats in tropical regions of the world (Richardson 2002) and indicate that the goats had been subjected to the influence of high AT and RH which required homeostatic adjustment to maintain thermoregulation.

During the transportation period, the high AT, RH and, solar radiation, and the concomitant effects of road transportation stress on the goats indicate that the meteorological conditions did not favour their transportation, especially during the afternoon hours of the day when the meteorological values attained their peak. At this period heat stress posed a significant threat to the homeostatic mechanisms of the goats. Similar findings that the hot-dry season is thermally stressful and characterized by high AT, $\mathrm{RH}$ and intense solar radiation were obtained by Ayo, Oladele, Fayomi, Jumbo \& Hambolu (1998). Such unfavourable meteorological conditions adversely affect the health status and productivity of animals (Bligh \& Bubemik 1980; Jindal 1980).

The insignificant change in chloride concentration recorded post-loading suggest that the stress induced by handling and loading of the goats did not induce acidosis. However, the significant $(P<0.05)$ increase in chloride concentration post-transportation recorded in control goats indicates that the transportation affected their acid-base balance, which might have resulted into stress acidosis. High AT and $\mathrm{RH}$ are known to cause increase in oxygen consumption, hyperthermia, dehydration, live mass 
loss and heat stress which are associated with respiratory alkalosis (Leeson 1986; Minka \& Ayo 2007b). The increase in chloride concentration obtained in this study was within the reference range of $82-110 \mathrm{mmol} / \ell$ (Smirnov, Konopelko, Pushkov, Postnikov, Urazav, Belkov, Digi \& Kondratyev 1987), and may be a compensatory response of the goats to primary respiratory alkalosis induced by the concomitant effects of road transportation stress and high AT and $\mathrm{RH}$. Similar increases in chloride as a result of transportation stress were observed in horses (Davidson, McConnico, Mitche, Hubert \& Coates-Markle 2004) and roe deer (Montane et al. 2002). However the result disagrees with that of Parker et al. (2003b) who failed to record any change in serum chloride concentrations in cattle transported for $48 \mathrm{~h}$.

The insignificant change in chloride concentrations obtained in the experimental goats suggest that $A A$ abolished the effect of factors that enhance respiratory alkalosis, by reducing heat load, and increasing their resistance to environmental stress, especially heat stress. Similar ameliorating effect of AA on heat load has been reported in goats (Minka \& Ayo 2007b) and poultry reared under heat stress (Minka \& Ayo 2008).

The average serum potassium level obtained in the control goats' post-transportation period decreased below the pre-loading and normal range value of 3.67-5.5 mmol/ (Ikhimioya \& Imasuem 2007). This result shows that the control goats suffered from muscular damage after the transportation, especially the skeletal muscles. Potassium is released from working muscles under stress or exercise due to glycogen depletion, changes in membrane permeability and increased cellular turnover, or is due to damage of the liver, erythrocytes and or skeletal muscle (Parker, Hamlin, Coleman \& Fitzpatrick 2003a). Similar observations on a decrease in serum potassium were reported in humans after completion of exercise, and in transported roe deer (Montane et al. 2002), cattle (Parker et al. 2003b) and horses (Codazza, Maffeo \& Redaelli 1974) due to muscular damage. The results obtained in the experimental group of goats further suggest the inhibitory effects of AA on stress hormones (Balz 2003) and its ability to alter neuro-muscular excitability.

The increase in sodium concentration $(160 \mathrm{mmol} / \mathrm{l})$ recorded in the control goats post-transportation was above the normal reference range values of 129 to $138.1 \mathrm{mmol} / \mathrm{\ell}$ established in West African Dwarf and Red Sokoto goats (Tambuwal, Agaie \& Bangana 2002; Daramola, Adeloye, Fatoba \& Soladoye
2005; Ikhimioya \& Imasuem 2007). The present results indicate that the goats were dehydrated after the Journey. This may be due to the fact that the AT and $\mathrm{RH}$ recorded during transportation were higher than the upper heat tolerance limit of $35^{\circ} \mathrm{C}$, established for goats in the tropical regions (Richardson 2002). Similar results were obtained in transported horses, though the concentration of sodium remained within the normal reference ranges (Davidson et al. 2004). The present results contradict those of Montane et al. (2002) who observed no change in sodium concentration after $4 \mathrm{~h}$ of transportation of roe deer. The insignificant change in sodium concentration obtained in the roe deer may be as a result of the short journey duration (9h) compared to the 12-h journey in the present study. The increase in sodium concentration post-transportation in the experimental goats administered AA was within the normal reference range for goats. This indicates that the AA may have been involved in the reduction of the adverse effects of high AT and RH which were responsible for increased oxygen consumption and dehydration.

The average increase in serum calcium levels recorded in the control goats post-transportation was above the reference values of $2.0-3.3 \mathrm{mmol} / \ell$ and 2.2-2.5 $\mathrm{mmol} / \mathrm{\ell}$ established in goats by Smirnov et al. (1987) and Piccione, Fazio, Giannetto, Assenza \& Caola (2007), respectively, which indicated that the muscles of the goats were highly active during the transportation. Such increase in muscular activity results in a rise in calcium ion concentration in the extracellular fluid (Klaus-Dietrich 1985). Calcium is reported to cause considerable intensification of the contractility of muscle cells, including heart muscle cells (Klaus-Dietrich 1985). The restoration of calcium base-line values 3 days post-transportation in the control goats suggest that their muscular activity was excessively stressed post-transportation. The present results contradict those of Parker et al. (2003b) who observed no significant increase in serum calcium ions of Bos indicus cattle transported for a long period, as well as those of Codazza et al. (1974) who observed a decrease in serum calcium levels in transported horses.

The results of the calcium concentration obtained in the goats in the experimental group further confirm the ameliorating effect of $A A$ on stressed muscle, probably through the protection of muscle cells from oxidative damage, membrane integrity and permeability. AA has also been reported to reduce dehydration and depletion of muscle glycogen in transported goats and pullets (Minka \& Ayo 2007b, 2008). 
The non-significant change in serum phosphate observed in the present study in experimental and control goats disagree with the findings of Codazza et al. (1974) who recorded a decrease of $5.4 \%$ in phosphate level of transported horses. The serum phosphate concentration recorded in the present study was within the reference values of 1.94-2.6 $\mathrm{mmol} / \mathrm{l}$ established for goats (Smirnov et al. 1987; Ikhimioya \& Imasuem 2007; Piccione et al. 2007).

The fact that the serum magnesium concentration recorded in the control goats post-transportation decreased above normal range value of $0.8-1.5$ $\mathrm{mmol} / \ell$ (Erdogan, Ergun, Erdogan \& Kontas 2002) suggested a serious energy deficiency in the goats' skeletal and cardiac muscle, since magnesium enhances mitochondrial respiration (Klaus-Dietrich 1985). The decrease in magnesium may have been due to loss from the body through an intracellular shift of magnesium. A similar decrease in serum magnesium concentration by $7.8 \%$ from pre-transport values was recorded in transported horses (Codazza et al. 1974). A decrease in magnesium value from $0.82 \mathrm{mmol} / \ell$ to $0.65 \mathrm{mmol} / \ell$ was recorded in goats due to isolation stress. Also, stress together with lack of magnesium causes an increase in the synthesis and release of catecholamines, resulting in an increase in cell permeability and distortion of the enzyme cholineacetylase (Al-Qarawi \& Ali 2005). These factors are known to reduce the immune status of an animal which may cause increased morbidity and mortality. The results obtained suggest that long duration of road transportation during the hot-dry season caused exhaustion of serum magnesium in the goats. The results obtained in the experimental group of goats indicated that AA reduced transportation stress and enhanced the utilization of magnesium, apart from its protective role on cellular damage.

The mechanism of action of AA on electrolyte balance is still obscure. The results of the few studies conducted in vivo have failed to obtain any direct relationship between AA and mineral balance (Eteng, Ibekwe, Amatey, Basey, Uboh \& Owu 2006).

Although AA administration to the transported goats alleviated the adverse effects of road transportation stress on electrolyte balance, the exact mechanism by which AA achieves this may indirectly be by inhibition of cortisol, the chief stress hormone, and by enhancing the adaptability of the goats through increased scavenging of free radicals often generated during heat stress and protection of cell membranes from lipid peroxidation (Altan, Pabuccuoglu, Altanb,
Konyalioglu \& Bayraktar 2003; Tauler et al. 2003). The results of the present study have provided, for the first time, information on the effects of a long duration (12 h) of road transportation, and the administration of AA on electrolytes of RSG during a hot-dry season, which have previously been lacking. Overall, the handling, loading, and transportation, together with the concomitant effect of hot weather disrupted the electrolyte balance of the goats which suggest that they suffered from respiratory alkalosis, dehydration and muscular damage.

In conclusion, the $12 \mathrm{~h}$ of road transportation during the hot-dry season was stressful and affected the electrolyte balance of the goats. The administration of AA alleviated the adverse effects of road transportation stress on serum electrolytes.

\section{ACKNOWLEDGMENTS}

We are grateful to the management of the College of Agriculture and Animal Science, Ahmadu Bello University, Mando-Kaduna, Nigeria.

\section{REFERENCES}

ANONYMOUS 1991. European Union Council Directive 91/628 on the Welfare of animals in transit as amended by Directive 95/29.

ALI, B.H., AL-QARAWI, A.A. \& MOUSA, H.M. 2006. Stress associated with road transportation in desert sheep and goats, and the effect of pre-treatment with xylazine or sodium betamine. Research in Veterinary Science, 80:343-348.

ALTAN, O., PABUCCUOGLU, A., ALTANB, A., KONYALIOGLU, S. \& BAYRAKTAR, H. 2003. Effect of heat stress on oxidative stress, lipid peroxidation and some stress parameters in broilers. British Poultry Science, 44:545-550.

AL-QARAWI, A.A. \& ALI, B.H. 2005. Isolation street in desert sheep and goats and the influence of pre-treatment with xylazine or sodium betamine. Veterinary Research Communications, 29:81-90.

ATKINSON, P.J. 1992. Investigation of the effects of transport and lairage on hydration state and resting behaviour of calves for export. Veterinary Record, 130:413-416.

AYO, J.O., MINKA, N.S. \& MAMMAN, M. 2006. Excitability scores of goats administered ascorbic acid and transported during hot dry conditions. Journal of Veterinary Science, 7: 127-131.

AYO, J.O., OLADELE, S.B., FAYOMI, A., JUMBO, S.D. \& HAMBOLU, J.O. 1998. Body temperature, respiration and heart rate in the Red Sokoto goat during the harmattan season. Bulletin of Animal Health and Production in Africa, 46:161166.

BALZ, F. 2003. Vitamin C intake. Nutritional Diseases, 14:1-8.

BLIGH, J. \& BUBEMIK, G.A. 1980. Effects of tropical climate on the physiology of cattle. Journal of Animal Production, 20: 343-352. 
CHERVYAKOV, D.K., YEVDOKIMOV, P.D. \& VISHKER, A.S. 1977. Drugs in veterinary medicine. Moscow: Kolos Publishing House (in Russian).

CHANG, X. \& MOWAT, D.N. 1992. Supplemental chromium for stressed and growing feeder calves. Journal of Animal Science, $70: 559$

CODAZZA, D., MAFFEO, G. \& REDAELLI, G. 1974. Serum enzyme change of haematochemical level in thoroughbred horses after transportation and exercise. Proceedings of the

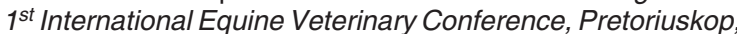
Kruger National Park: 1974:45.

DARAMOLA, J.O., ADELOYE, A.A, FATOBA, T.A. \& SOLADOYE, A.O. 2005. Hematological and biochemical parameters of West African Dwarf goats. Livestock Research for Rural Development. from http//www.cpav.org.co/irrd/17/ 8dara17095.htm.

DAVIDSON, A., MCCONNICO, R., MITCHE II, M., HUBERT, J. \& COATES-MARKLE, L. 2004. The effect of pre-treatment with oral electrolytes on serum cortisol and other haematological parameters in a group of feral horses transported by road. The Veterinary Journal, 168:194-203.

ERDOGAN, S., ERGUN, Y., ERDOGAN, Z. \& KONTAS, T. 2002. Some mineral substance levels in serum of sheep and goat grazing in Hatay region. Turkish Journal of Veterinary Science, 26:177-182.

ETENG, M.U., IBEKWE, H.A., AMATEY, T.E., BASEY, B.J.J., UBOH, F.U. \& OWU, D.U. 2006. Effect of vitamin C on serum lipids and electrolytes profile of albino Wistar rats. Nigerian Journal of Physiological Science, 21:9-15.

FARM ANIMAL WELFARE COUNCIL ((FAWC) 2003. Farm animal at slaughter or killing. Part 1. London: Defra Publications.

GALIPALLI, S., GADIYARAM, K.M., KOUAKOU, B., TERRIL, T.H \& KANNAN, G. 2004. Physiological responses to preslaughter transportation stress in Tasco-supplemented goats. South African Journal of Animal Science, 34:198-200.

GREENWOOD, P.C., MAY, T.J. \& FINN, J.A. 1993. Development of object methods for marketing and promotion of goat meat Agriculture: Final report for 1993. 041. Sydney: MRC/NSW.

HASSANZADEH, L.M., BUYS, N., DEWL, E., RAHIMI, G. \& GECUYPERE, E. 1997. The prophylactic effects of vitamin C supplementation on broilers' ascites incidence and plasma thyroid hormones concentration. Avian Pathology, 26:33-34.

IKHIMIOYA, I. \& IMASUEM, J.A. 2007. Blood profile of West African Dwarf goats fed Panicum maximum supplemented with Afzelia africana and Newboudia laevis. Pakistan Journal of Nutrition, 6:79-84.

JINDAL, S.K. 1980. Effect of climate on goats: A review. Indian Journal of Dairy Science, 33:285-293.

KANNAN, G., TERRIL, T.H., KOUOKOU, B., GELAYE, S. \& AMOAH, E.A. 2002. Simulated preslaughter holding and isolation effects on stress responses and livemass shrinkage in meat goats. Journal of Animal Science, 80:1771-1780.

KANEKO, J.J. 1980. Clinical biochemistry of domestic animals, $3^{\text {rd }}$ ed. Orlando, Florida: Academic Press.

KLAUS-DIETRICH, G. 1985. Stress behaviour of animals and its effects on the mineral balance. Journal of Animal Research and Development, 68:17-33.

KNOWLES, T.G., WARRISS, P.D., BROWN, S.N. \& EDWARDS, J.E. 1999. Effects on cattle of transportation by road for up to 31 hours. Veterinary Record, 145:575-582.

LEESON, S. 1986. Nutritional considerations of poultry during heat stress. World's Poultry Science Journal, 42:69-81.
MINKA, N.S. \& AYO, J.O. 2007a. Effects of loading behaviour and road transportation stress on traumatic injuries in cattle transported by road during the hot-dry season. Livestock Science, 107:91-95.

MINKA, N.S. \& AYO, J.O. 2007b. Physiological responses of transported goats treated with ascorbic acid during the hotdry season. Animal Science Journal, 78:164-172.

MINKA, N.S. \& AYO, J.O. 2008. Haematology and behaviour of pullets transported by road and administered with ascorbic acid during the hot dry season. Research in Veterinary Science, 85:389-393.

MONTANE, J., MARCO, I., LOPEZ-OLVERA, J., MANTECA, X. \& LAVIN, S. 2002. Transport stress in roe deer (Capreolus capreolus): Effect of short acting antipsychotic. Animal Welfare, 11:295-303.

NIKITCHENKO, I.N., PLYASCHENKO, S.I. \& ZENKOV, A.C. 1988. Stresses and productivity of farm animals. Minsk: Urajai Publishing House (in Russian).

PARKER, A.J., HAMLIN, G.P., COLEMAN, C.J. \& FITZPATRICK, L.A. 2003a. Dehydration in stressed ruminants may be the result of a cortisol-induced diuresis. Journal of Animal Science, 81:512-519.

PARKER, A.J., HAMLIN, G.P., COLEMAN, C.J. \& FITZPATRICK, L.A. 2003b. Quantitative analysis of acid-base balance in Bos indicus steers subjected to transportation of long duration. Journal of Animal Science, 81:1434-1439.

PICCIONE, G., FAZIO, F., GIANNETTO, C., ASSENZA, A. \& CAOLA, G. 2007. Oxidative stress in thoroughbreds during official 1800-meter races. Veterinarski Arhiv, 77:219-227.

PHILIPS, A. 1997. Electrolyte and sugar supplements for slaughter cattle transported long distances. NTA 020. Meat Research Corporation: Sydney, Australia.

PLYASCHENKO, S.I. \& SIDOROV, V.T. 1987. Stresses in farm animals. Moscow: Agropromizdat (in Russian).

RAJION, M.A., SOAT, I.M., ZULKIFLI, I. \& GOH, Y.M. 2001. The effects of road transportation on some physiological stress measures in goats. Asian-Australian Journal of Animal Science, 9:1250-1252.

RICHARDSON, C. 2002. Lowering stress in transported goats. Ontario Ministry of Agriculture and Food-Livestock Technology Branch: Northern Ontario Regional Office.

ROSS, J.G., SPEARS, J.W. \& GARLICH, J.D. 1994. Dietary electrolyte balance effects on performance and metabolic characteristics in growing steers. Journal of Animal Science, 72:1842-1847.

SCHAEFER, A.L., JONES, S.D.M. \& STANLEY, R.W. 1997. The use of an electrolyte solution for reducing transport stress. Journal of Animal Science, 75:258-265.

SCHAEFER, A.L., JONES S.D.M., TONG, A.K.W. \& YOUNG, B.A. 1990. Effects of transport and electrolyte supplementation on ion concentration, carcass yield and quality in bulls. Canadian Journal of Animal Science, 70:107-114.

SMIRNOV, A.M., KONOPELKO, P.Y., PUSHKOV, S.P., POSTNIKOV, V.S., URAZAV, N.A., BELKOV, I.M., DIGI, G.L. \& KONDRATYEV, V.C. 1987. Methods of clinical examination, in Internal non-infectious diseases of animals, edited by A.M. Smirnov Moscow: Kolos Press (in Russian).

SRANMEK, J. \& POZDESEU, J. 1987. The effect of sodium chloride supplementation on the content of sodium and potassium in the blood plasma and on sodium and potassium retention in heifers. Zivocisma vyroba, 32:515. 
Serum electrolytes of goats during hot-dry season in Nigeria, and effect of pretreatment with ascorbic acid

TAMBUWAL, F.M., AGAIE, B.M. \& BANGANA, A. 2002. Haematological and biochemical values of apparently healthy Red Sokoto goats. Proceedings of the $27^{\text {th }}$ Annual Conference of the Nigerian Society for Animal Production, Federal University, Akure, Nigeria, 2002: 50-53.
TAULER, P., AGUILO, A., GIMENO, I., FUENTESPIS, E., TUR, J.A. \& PONS, A. 2003. Influence of vitamin C supplementation on endogenous antioxidant defence during exhaustive exercise. European Journal of Physiology, 440:658-664. 